\title{
Trends of Oxygen Saturation of Newborns after Birth from Northern India
}

\author{
Ambey $\mathbf{R}^{1}$, Bansal $\mathbf{A}^{2}$, Das $\mathbf{G}^{3}$ \\ ${ }^{1}$ Dr Ravi Ambey, Assistant Professor, ${ }^{2}$ Dr Akanksha Bansal, Senior Resident, ${ }^{3}$ Dr Ghanshyam Das, Associate Professor. \\ All are affiliated with Department of Pediatrics, Gajra Raja Medical College, Gwalior, Madhya Pradesh, India. \\ Address for Correspondence: Dr. Ravi Ambey, Assistant Professor, Department of Pediatrics, Gajra Raja Medical \\ College, Gwalior, Madhya Pradesh. Email: ravi_ambey97@yahoo.co.in
}

\begin{abstract}
Aim: 1) To present the percentiles of oxygen saturation for newborns from Northern Indian set-up and to compare it with the reference range provided. 2) To analyze and compare the progression of oxygen saturation in term and preterm newborns. Background: Even after knowing that preterm newborns may have different physiological requirements, they are being treated as similar entity as term newborns. No separate reference oxygen saturation ranges are available for them. Also little data is available about the percentiles of oxygen saturations for newborns in Indian set-up. Material Methods: This was a Prospective Observational study done over a period of one year at a tertiary care hospital. 500 newborns with gestational age of 28-42 weeks, requiring routine care were enrolled. Oxygen saturation readings were recorded separately for term and preterm newborns till 10 minutes of life. Results: $\mathrm{SpO} 2$ values of preterm newborns rises slowly as compared to term newborns. It took a mean time of $7.77 \pm 1.45 \mathrm{~min}$ (IQR of $6.3-9$ minutes) for term newborns and $8.78 \pm 0.97 \mathrm{~min}$ (IQR of 8.3-9.3 minutes) for preterm newborns to reach $\geq 85 \% \mathrm{SpO} 2$. The $3^{\text {rd }}, 10^{\text {th }}, 25^{\text {th }}$, $50^{\text {th }}, 75^{\text {th }}, 90^{\text {th }}$ and $97^{\text {th }}$ percentiles of oxygen saturation have been calculated for both term and preterm newborns from birth till 10 minutes of life. Conclusion: Preterm newborns should be treated as separate entity from term newborns to keep them safe from hazards of oxygen toxicity. This study provides the reference percentiles of oxygen saturation for term and preterm newborns from Northern India separately.
\end{abstract}

Key words: Colour, Cyanosis, Newborn $\mathrm{SPO}_{2}$, Oxygen saturation, Reference $\mathrm{SPO}_{2}$

\section{Introduction}

Introduction of pulse oximetry to assess the newborn's oxygenation status has revolutionized the world of pediatricians. Before that, assessment of newborn's colour was the sole indicator of newborn's oxygenation status and which had its own limitations [1]. The decision to give supplemental oxygen was also based only on the visual perception of colour and with time it was proved detrimental to both term and preterm newborns. Clinicians are responsible for titrating oxygen to maximize the benefits and minimize the risks of this therapy [2].

In 2010, The International Liaison Committee on Resuscitation (ILCOR) has introduced the concept of pulse oximetry in place of visual assessment of colour

Manuscript received: $14^{\text {th }}$ May 2016

Reviewed: $26^{\text {th }}$ May 2016

Author Corrected; $11^{\text {th }}$ June 2016

Accepted for Publication: $25^{\text {th }}$ June 2016 for both term and preterm newborns in the algorithm for neonatal resuscitation. Also ILCOR has provided the reference ranges for oxygen saturation which are calculated on the basis of existing data on oxygen saturation in healthy term newborns in the first few minutes of life $[3,4]$. Since long, it has been known that preterm newborns may have some different physiological requirements than term newborns. They are most susceptible even to the minute deficiency or excess of a drug called 'oxygen'. Oxygen is the most commonly used therapy in neonatal nurseries as an integral part of respiratory support.

The goal of oxygen therapy is to achieve adequate delivery of oxygen to the tissue without creating oxygen toxicity [5]. Neither the amount of oxygen to be used, nor the reference target oxygen saturation ranges has been provided separately for preterm newborns. 
Moreover most of the data is acquired from the western world for the calculation of reference oxygen saturation ranges and it may not have a similar applicability for newborns in Indian set-up in view of its different geographical, ethical and racial background and other factors.

Hence this study was conducted hypothesizing that newborns in Indian set-up may have a different pattern of attainment of oxygen saturation after birth than newborns in the western world and it may also vary between term and preterm newborns. So it is required that we should have a separate set of reference range of oxygen saturation for term and preterm newborns in Indian set-up.

\section{Material and Method}

Place and type of study: This was a prospective observational study, conducted in the department of Pediatrics, Gajra Raja Medical College and Kamla Raja Hospital, Gwalior, Madhya Pradesh, India.

The study was done in the labour room and operation theatre along with the attached level-3 Special Care Newborn Unit (SNCU) over a period of one year from August 2012 to July 2013.

Ethical Approval: Appropriate ethical approval from the Institutional Ethical Committee was taken before the commencement of this study.

Sample size calculation: A sample size of 357 newborns was obtained with $95 \%$ confidence interval taking into account that approximately 5000-6000 deliveries are conducted in the hospital per year. A sample size of 500 newborns was considered in this study in order to have a larger sample size so that we can generalize the results.

Inclusion Criteria: Newborns between the gestational age of 28 weeks to 42 weeks (by New Ballard scoring) [6], delivered by either normal vaginal route or caesarean section were included in this study.

Exclusion Criteria: Newborns with major congenital anomalies, requiring supplemental oxygen, medical intervention or resuscitation of any kind, extremely low birth weight (ELBW) and those born with meconium stained amniotic fluid were excluded.

Newborns in which we failed to apply probes or probe was detached were also excluded.
Procedure: After taking a written informed consent from the relatives in all cases before delivery, all the enrolled newborns were divided into Term ( $\geq 37$ weeks to $\leq 42$ weeks) and Preterm ( $\geq 28$ weeks to $<37$ weeks) as per their gestational age. Masimo rad 5 pulse oximeter with signal extraction technology (SET) was used in the present study, which provides reliable readings even in low perfusion states and with patient movements $[7,8]$.

Pulse oximeter was equipped with in-built recording of $\mathrm{SpO}_{2}$ and heart rate at every 2 second interval in the form of trend chart and was set to acquire data with maximal sensitivity.

Immediately after birth of the newborn, umbilical cord was clamped and a stop watch was started. Newborn was taken in a pre-warmed towel and the probe of the pulse oximeter, which was specially designed for newborns, was attached to the newborn's right hand's wrist and then connected to the pulse oximeter.

The observer was not involved in the process of resuscitation and the whole process was conducted in the presence of a resident trained in neonatal resuscitation. Immediately the newborn was kept on a resuscitation trolley under a radiant warmer.

The procedure was followed keeping in mind the guidelines and precautions as described by American Academy of Pediatrics [2, 3, 9].

Data Collection and Stastical Analysis: Data collection for each newborn was done both manually as well as from the trend chart stored within the pulse oximeter at every 30 second interval. Also time to record the first data of $\mathrm{SpO}_{2}$ after applying the probe and time taken to acquire $\mathrm{SpO}_{2} \geq 85 \%$ and $\geq 90 \%$ was recorded in each case. Individual readings of $\mathrm{SpO}_{2}$ and time were then entered in separate excel spread sheets which were then merged and analyzed with Minitab software.

$\mathrm{Z}$ test was applied to determine the mean time for getting pink, mean time for recording first data of $\mathrm{SpO}_{2}$ and mean time to reach $\geq 85 \%$ and $\geq 90 \%$ saturation in term and preterm newborns in both the groups. Mann Whitney U test was used to compare the median Spo2 in term and preterm newborns in both the groups. For percentile chart preparation, individual data was entered in customized excel spreadsheets which were then analyzed. 


\section{Results}

Out of total 500 newborns enrolled in this study, 81 were excluded (33 required resuscitation, 13 were born with meconium stained amniotic fluid, 11 were with congenital anomalies, 12 were ELBW and in 12 cases either the probe was not applied in time or it was detached in between). So total 419 newborns remained in the present study, which were then divided into term (301) and preterm (118) as per their gestational age.

The mean \pm SD gestational age of infants included in the study was $34.93 \pm 1.32$ weeks for preterm and $39.02 \pm 0.08$ weeks for term newborns and the mean birth weight $(\mathrm{Kg}) \pm \mathrm{SD}$ was $1.98 \pm 0.08 \mathrm{Kg}$ for preterm and $2.621 \pm 0.010 \mathrm{Kg}$ for term newborns. The characteristics of the newborns are presented in (Table-1).

Table- 1: Newborn's Characteristics.

\begin{tabular}{|c|c|c|c|}
\hline \multirow{2}{*}{ Newborn's Characteristics } & \multicolumn{2}{|c|}{ Routine care } & \multirow{2}{*}{ Total } \\
\cline { 2 - 4 } & No. & \% & \multirow{2}{*}{419} \\
1.Gender Distribution & 223 & 53.22 & \\
Male & 196 & 46.77 & \multirow{2}{*}{419} \\
\hline 2.Gestation & 118 & 28.16 & \\
28-36.6 wks & 301 & 71.83 & \\
37-42 wks & 18 & & \\
\hline 3.Birth Weight & 137 & 3.29 & \\
1001-1499 g & 264 & 63.00 & \\
1500-2499 g & & & \\
$\geq 2500 \mathrm{~g}$ & 248 & 59.18 & \\
\hline 4. Mode of delivery & 171 & 40.81 & \\
\hline NVD & & & \\
\hline
\end{tabular}

Mean time (minutes) $\pm \mathrm{SD}$ of recording first data of $\mathrm{SpO}_{2}$ in all newborns was $0.987 \pm 0.549$ minutes with a standard error of mean of 0.035. On comparing the median $\mathrm{SpO}_{2}$ values of term and preterm newborns from birth till 10 minutes of life (Table- 2), it has been found that the $\mathrm{SpO}_{2}$ values rises slowly in preterm newborns as compared to term newborns, though both acquire $\geq 90 \%$ saturation with in the 10 minutes period.

It took a mean time of $7.77 \pm 1.45 \mathrm{~min}$ (IQR of 6.3-9 minutes) for term newborns and $8.78 \pm 0.97 \mathrm{~min}$ (IQR of 8.3-9.3 minutes) for preterm newborns to reach $\geq 85 \% \mathrm{SpO}_{2}$ and a mean of $8.35 \pm 1.16 \mathrm{~min}$ (IQR of 7.3 to $9.3 \mathrm{~min}$ ) for term and $9.32 \pm 0.59 \mathrm{~min}$ (IQR of 9-10min) for preterm to reach the $\mathrm{SpO}_{2} \geq 90 \%$.

Also in this study $3^{\text {rd }}, 10^{\text {th }}, 25^{\text {th }}, 50^{\text {th }}, 75^{\text {th }}, 90^{\text {th }}$ and $97^{\text {th }}$ percentiles of oxygen saturation were calculated separately for term, preterm and all newborns from birth till 10 minutes of life. For term newborns, these percentiles at 1 minute were $55 \%, 56 \%, 58 \%, 59 \%, 61 \%, 63 \%$ and $64 \%$, at 2 minutes were $60 \%, 61 \%, 63 \%, 65 \%, 67 \%, 68 \%$ and $70 \%$ and at 5 minutes were $72 \%, 74 \%, 79 \%, 83 \%, 85 \%, 87 \%$ and $88 \%$ respectively.

For preterm newborns, these percentiles at 1 minute were $52.97 \%, 56 \%, 57 \%, 58 \%, 59.25 \%, 61.1 \%$ and $63.03 \%$, at 2 minutes were $62 \%, 63 \%, 64 \%, 65 \%, 66 \%, 67 \%$ and $68.73 \%$ and at 5 minutes were $75 \%, 76 \%, 78 \%, 79 \%, 82 \%, 83 \%$ and $84 \%$ respectively. Similarly the percentiles at different time intervals for both the groups have been calculated (Table No$3,4,5)$ and presented in the form of smooth curved percentile charts (Figure-1 and 2). 
Table - 2: Comparison of $\mathrm{SpO}_{2}$ values at 1 to 10 minutes after birth.

\begin{tabular}{|c|c|c|c|c|}
\hline \multirow[t]{2}{*}{ Time } & \multicolumn{4}{|c|}{$\mathrm{S}_{\mathrm{P}} \mathrm{O}_{2}$ VALUES (\%) } \\
\hline & Preterm (Q1-Q3) & Term (Q1-Q3) & All Infants (Q1-Q3) & P value \\
\hline Birth & $43.5(40-46.75)$ & $47(46-50)$ & $46.5(45-49)$ & $\mathrm{p}<0.01$ \\
\hline $30 \mathrm{sec}$ & $49(45-54)$ & $52(50-55)$ & $52(49-54)$ & $\mathrm{p}<0.01$ \\
\hline $1 \mathrm{~min}$ & $58(57-59.25)$ & $59(58-61)$ & $59(57-61)$ & $\mathrm{p}<0.01$ \\
\hline $1 \mathrm{~min} 30 \mathrm{sec}$ & $62(61-63)$ & $62.5(61-64)$ & $62(61-64)$ & $\mathrm{p}>0.05$ \\
\hline $2 \mathrm{~min}$ & $65(64-66)$ & $65(63-67)$ & $65(63-66)$ & $\mathrm{p}>0.05$ \\
\hline $2 \mathrm{~min} 30 \mathrm{sec}$ & $67(66-69)$ & $68(64-70)$ & $68(65-70)$ & $\mathrm{p}>0.05$ \\
\hline $3 \mathrm{~min}$ & $70(69-71)$ & $71(69-72)$ & $70(69-72)$ & $\mathrm{p}>0.05$ \\
\hline $3 \min 30 \mathrm{sec}$ & $73(71-74)$ & $74(70-75)$ & $73(70-75)$ & $\mathrm{p}>0.05$ \\
\hline $4 \mathrm{~min}$ & $75(73-76)$ & $76(73-78)$ & $75(73-77)$ & $\mathrm{p}<0.05$ \\
\hline $4 \mathrm{~min} 30 \mathrm{sec}$ & $77(75-79)$ & $79(75-82)$ & $78(75-81)$ & $\mathrm{p}<0.01$ \\
\hline $5 \mathrm{~min}$ & $79(78-82)$ & $83(79-85)$ & $81(78-84)$ & $\mathrm{p}<0.01$ \\
\hline $5 \mathrm{~min} 30 \mathrm{sec}$ & $82(81-84)$ & $85(80-88)$ & $84(80-87)$ & $\mathrm{p}<0.01$ \\
\hline $6 \mathrm{~min}$ & $85(83-87)$ & $87(83-89)$ & $86(83-89)$ & $\mathrm{p}<0.01$ \\
\hline $6 \mathrm{~min} 30 \mathrm{sec}$ & $87(85-89)$ & $89(85-91)$ & $88(85-90)$ & $\mathrm{p}<0.01$ \\
\hline $7 \mathrm{~min}$ & $88(85-89)$ & $91(87-93)$ & $89(86-93)$ & $\mathrm{p}<0.01$ \\
\hline $7 \min 30 \mathrm{sec}$ & $89(86.25-90)$ & $93(88-95)$ & $91(88-94)$ & $\mathrm{p}<0.01$ \\
\hline $8 \mathrm{~min}$ & $90(89-93)$ & $94(90-95)$ & $93(89-95)$ & $\mathrm{p}<0.01$ \\
\hline $8 \mathrm{~min} 30 \mathrm{sec}$ & 93(91-94) & $95(91-96)$ & $94(91-96)$ & $\mathrm{p}<0.01$ \\
\hline $9 \mathrm{~min}$ & $95(93-96)$ & $96(93-97)$ & $96(93-97)$ & $\mathrm{p}<0.01$ \\
\hline $9 \mathrm{~min} 30 \mathrm{sec}$ & $95(95-97)$ & $97(95-98)$ & $97(95-97)$ & $\mathrm{p}<0.01$ \\
\hline $10 \mathrm{~min}$ & $97(96-98)$ & 97(96-98) & $97(96-98)$ & $\mathrm{p}>0.05$ \\
\hline
\end{tabular}

Table- 3: Percentiles of oxygen saturation of overall newborns (Term and Preterm) after birth.

\begin{tabular}{|c|c|c|c|c|c|c|c|}
\hline \multirow[b]{2}{*}{ Time after Birth } & \multicolumn{7}{|c|}{ Percentiles of oxygen saturation } \\
\hline & $3^{\text {rd }}$ & $10^{\text {th }}$ & $25^{\text {th }}$ & $50^{\text {th }}$ & $75^{\text {th }}$ & $90^{\text {th }}$ & $97^{\text {th }}$ \\
\hline Birth & 32 & 40 & 45 & 46 & 49 & 51 & 53.14 \\
\hline $30 \mathrm{Sec}$ & 43 & 46 & 49 & 52 & 55 & 57 & 59 \\
\hline $1 \mathrm{~min}$ & 55 & 56 & 57 & 59 & 61 & 62 & 64 \\
\hline $1 \mathrm{~min} 30 \mathrm{sec}$ & 58 & 59 & 61 & 62 & 64 & 65 & 67 \\
\hline $2 \mathrm{~min}$ & 60 & 62 & 63 & 65 & 66 & 68 & 69.82 \\
\hline $2 \min 30 \mathrm{sec}$ & 62 & 63 & 65 & 68 & 70 & 72 & 74 \\
\hline $3 \mathrm{~min}$ & 65 & 66 & 69 & 70 & 72 & 74 & 75 \\
\hline $3 \min 30 \mathrm{sec}$ & 66 & 68 & 70 & 73 & 75 & 76 & 80 \\
\hline $4 \mathrm{~min}$ & 68 & 70 & 73 & 75 & 77 & 78 & 80 \\
\hline $4 \mathrm{~min} 30 \mathrm{sec}$ & 70 & 73 & 75 & 78 & 81 & 83 & 84 \\
\hline $5 \mathrm{~min}$ & 73 & 75 & 78 & 81 & 84 & 87 & 88 \\
\hline $5 \mathrm{~min} 30 \mathrm{sec}$ & 75 & 77 & 80 & 84 & 87 & 89 & 89 \\
\hline $6 \mathrm{~min}$ & 78 & 80 & 83 & 86 & 89 & 90 & 92 \\
\hline $6 \mathrm{~min} 30 \mathrm{sec}$ & 80 & 82 & 85 & 88 & 90 & 93 & 94 \\
\hline $7 \mathrm{~min}$ & 81 & 84 & 86 & 89 & 93 & 94 & 96 \\
\hline $7 \mathrm{~min} 30 \mathrm{sec}$ & 83 & 85 & 88 & 91 & 94 & 95 & 96 \\
\hline $8 \mathrm{~min}$ & 85 & 86 & 89 & 93 & 95 & 96 & 97 \\
\hline $8 \min 30 \mathrm{sec}$ & 88 & 89 & 91 & 94 & 96 & 97 & 97 \\
\hline $9 \mathrm{~min}$ & 90 & 91 & 93 & 96 & 97 & 97 & 99 \\
\hline $9 \min 30 \mathrm{sec}$ & 92 & 94 & 95 & 97 & 97 & 98 & 99 \\
\hline $10 \mathrm{~min}$ & 95 & 95 & 96 & 97 & 98 & 99 & 100 \\
\hline
\end{tabular}


Table -4: Percentiles of oxygen saturation for Term newborns after birth.

\begin{tabular}{|c|c|c|c|c|c|c|c|}
\hline \multirow[b]{2}{*}{ Time after birth } & \multicolumn{7}{|c|}{ Percentiles of oxygen saturation } \\
\hline & $3^{\text {rd }}$ & $10^{\text {th }}$ & $25^{\text {th }}$ & $\mathbf{5 0}^{\text {th }}$ & $75^{\text {th }}$ & $90^{\text {th }}$ & $97^{\text {th }}$ \\
\hline Birth & 40.64 & 43.8 & 46 & 47 & 50 & 51.6 & 53.68 \\
\hline $30 \mathrm{Sec}$ & 43 & 46.3 & 50 & 52 & 55 & 56.7 & 59 \\
\hline $1 \mathrm{~min}$ & 55 & 56 & 58 & 59 & 61 & 63 & 64 \\
\hline $1 \mathrm{~min} 30 \mathrm{sec}$ & 58 & 59 & 61 & 62.5 & 64 & 65 & 67 \\
\hline $2 \mathrm{~min}$ & 60 & 61 & 63 & 65 & 67 & 68 & 70 \\
\hline $2 \mathrm{~min} 30 \mathrm{sec}$ & 61 & 63 & 64 & 68 & 70 & 73 & 74 \\
\hline $3 \mathrm{~min}$ & 64 & 66 & 69 & 71 & 72 & 74 & 75.03 \\
\hline $3 \min 30 \mathrm{sec}$ & 66 & 68 & 70 & 74 & 75 & 77 & 80 \\
\hline $4 \mathrm{~min}$ & 68 & 69 & 73 & 76 & 78 & 79 & 80 \\
\hline $4 \mathrm{~min} 30 \mathrm{sec}$ & 70 & 72 & 75 & 79 & 82 & 83 & 84 \\
\hline $5 \mathrm{~min}$ & 72 & 74 & 79 & 83 & 85 & 87 & 88 \\
\hline $5 \mathrm{~min} 30 \mathrm{sec}$ & 75 & 76 & 80 & 85 & 88 & 89 & 89 \\
\hline $6 \mathrm{~min}$ & 78 & 79 & 83 & 87 & 89 & 91 & 92 \\
\hline $6 \mathrm{~min} 30 \mathrm{sec}$ & 80 & 82 & 85 & 89 & 91 & 94 & 94 \\
\hline $7 \mathrm{~min}$ & 82 & 84 & 87 & 91 & 93 & 95 & 96 \\
\hline $7 \mathrm{~min} 30 \mathrm{sec}$ & 84 & 85 & 88 & 93 & 95 & 96 & 96 \\
\hline $8 \mathrm{~min}$ & 85 & 87 & 90 & 94 & 95 & 96 & 97 \\
\hline $8 \mathrm{~min} 30 \mathrm{sec}$ & 88 & 89 & 91 & 95 & 96 & 97 & 98 \\
\hline $9 \mathrm{~min}$ & 90 & 91 & 93 & 96 & 97 & 97 & 99 \\
\hline $9 \min 30 \mathrm{sec}$ & 94 & 94 & 95 & 97 & 98 & 98 & 99 \\
\hline $10 \mathrm{~min}$ & 95 & 96 & 96 & 97 & 98 & 99 & 99 \\
\hline
\end{tabular}

Table - 5: Percentiles of oxygen saturation for Preterm newborns after birth.

\begin{tabular}{|c|c|c|c|c|c|c|c|}
\hline \multirow[b]{2}{*}{ Time after birth } & \multicolumn{7}{|c|}{ Percentiles of oxygen saturation } \\
\hline & $3^{\text {rd }}$ & $10^{\text {th }}$ & $25^{\text {th }}$ & $\mathbf{5 0}^{\text {th }}$ & $7^{\text {th }}$ & $90^{\text {th }}$ & $97^{\text {th }}$ \\
\hline Birth & 32 & 36.2 & 40 & 43.5 & 46.75 & 49 & 50.96 \\
\hline $30 \mathrm{Sec}$ & 43 & 45 & 45 & 49 & 54 & 57.6 & 59.00 \\
\hline $1 \mathrm{~min}$ & 52.97 & 56 & 57 & 58 & 59.25 & 61.1 & 63.03 \\
\hline $1 \mathrm{~min} 30 \mathrm{sec}$ & 59.15 & 60 & 61 & 62 & 63 & 64.5 & 65.85 \\
\hline $2 \mathrm{~min}$ & 62 & 63 & 64 & 65 & 66 & 67 & 68.73 \\
\hline $2 \min 30 \mathrm{sec}$ & 64 & 65 & 66 & 67 & 69 & 70 & 70 \\
\hline $3 \mathrm{~min}$ & 67.48 & 68 & 69 & 70 & 71 & 72.4 & 74 \\
\hline $3 \min 30 \mathrm{sec}$ & 68 & 70 & 71 & 73 & 74 & 75 & 76 \\
\hline $4 \mathrm{~min}$ & 70 & 72 & 73 & 75 & 76 & 77 & 78 \\
\hline $4 \mathrm{~min} 30 \mathrm{sec}$ & 73 & 74 & 75 & 77 & 79 & 81 & 82 \\
\hline $5 \mathrm{~min}$ & 75 & 76 & 78 & 79 & 82 & 83 & 84 \\
\hline $5 \mathrm{~min} 30 \mathrm{sec}$ & 76 & 79 & 81 & 82 & 84 & 85 & 86 \\
\hline $6 \mathrm{~min}$ & 79 & 80 & 83 & 85 & 87 & 88 & 89 \\
\hline $6 \mathrm{~min} 30 \mathrm{sec}$ & 80 & 82 & 85 & 87 & 89 & 90 & 92 \\
\hline $7 \mathrm{~min}$ & 80 & 84 & 85 & 88 & 89 & 90 & 93 \\
\hline $7 \mathrm{~min} 30 \mathrm{sec}$ & 83 & 85 & 86 & 89 & 90 & 93 & 94 \\
\hline $8 \mathrm{~min}$ & 85 & 86 & 89 & 90 & 93 & 94 & 95 \\
\hline $8 \mathrm{~min} 30 \mathrm{sec}$ & 88 & 88 & 91 & 93 & 94 & 95 & 96 \\
\hline $9 \mathrm{~min}$ & 90 & 91 & 93 & 95 & 96 & 97 & 99 \\
\hline $9 \min 30 \mathrm{sec}$ & 90 & 93 & 95 & 95 & 97 & 98 & 99 \\
\hline $10 \mathrm{~min}$ & 94 & 95 & 96 & 97 & 98 & 99 & 100 \\
\hline
\end{tabular}




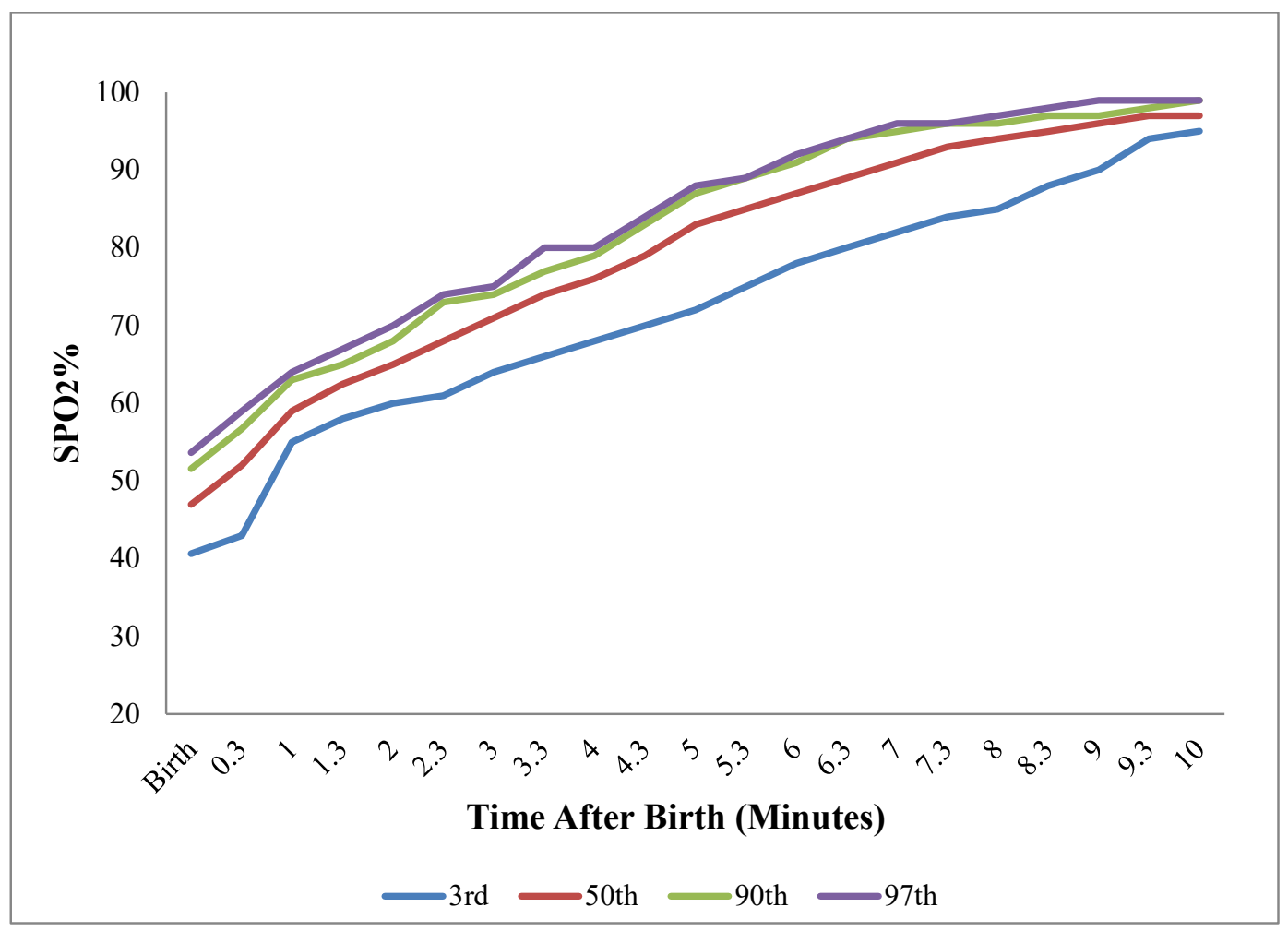

Figure 1: Percentiles of oxygen saturation in term newborns requiring routine care.

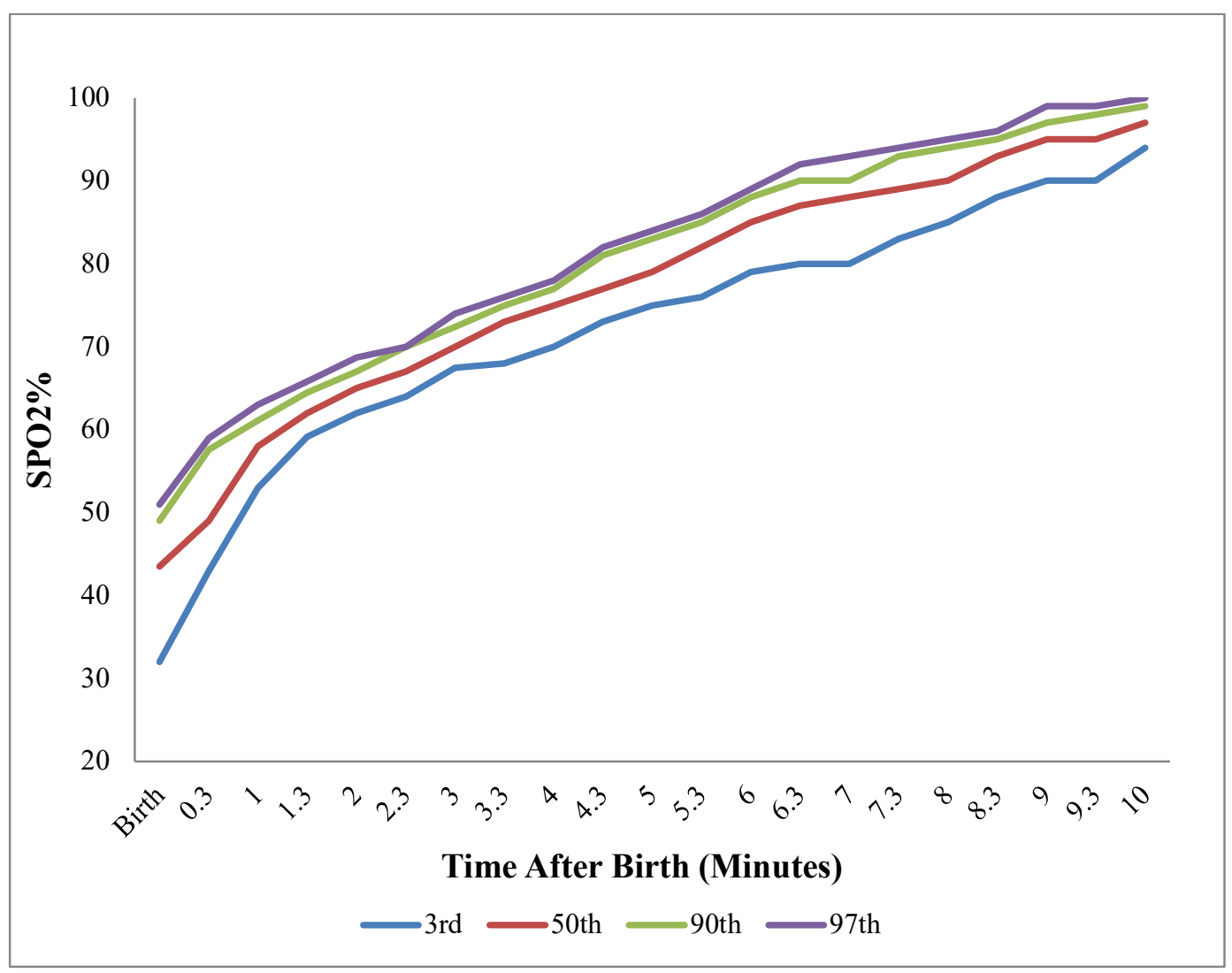

Figure 2: Percentiles of oxygen saturation in preterm newborns requiring routine care. 


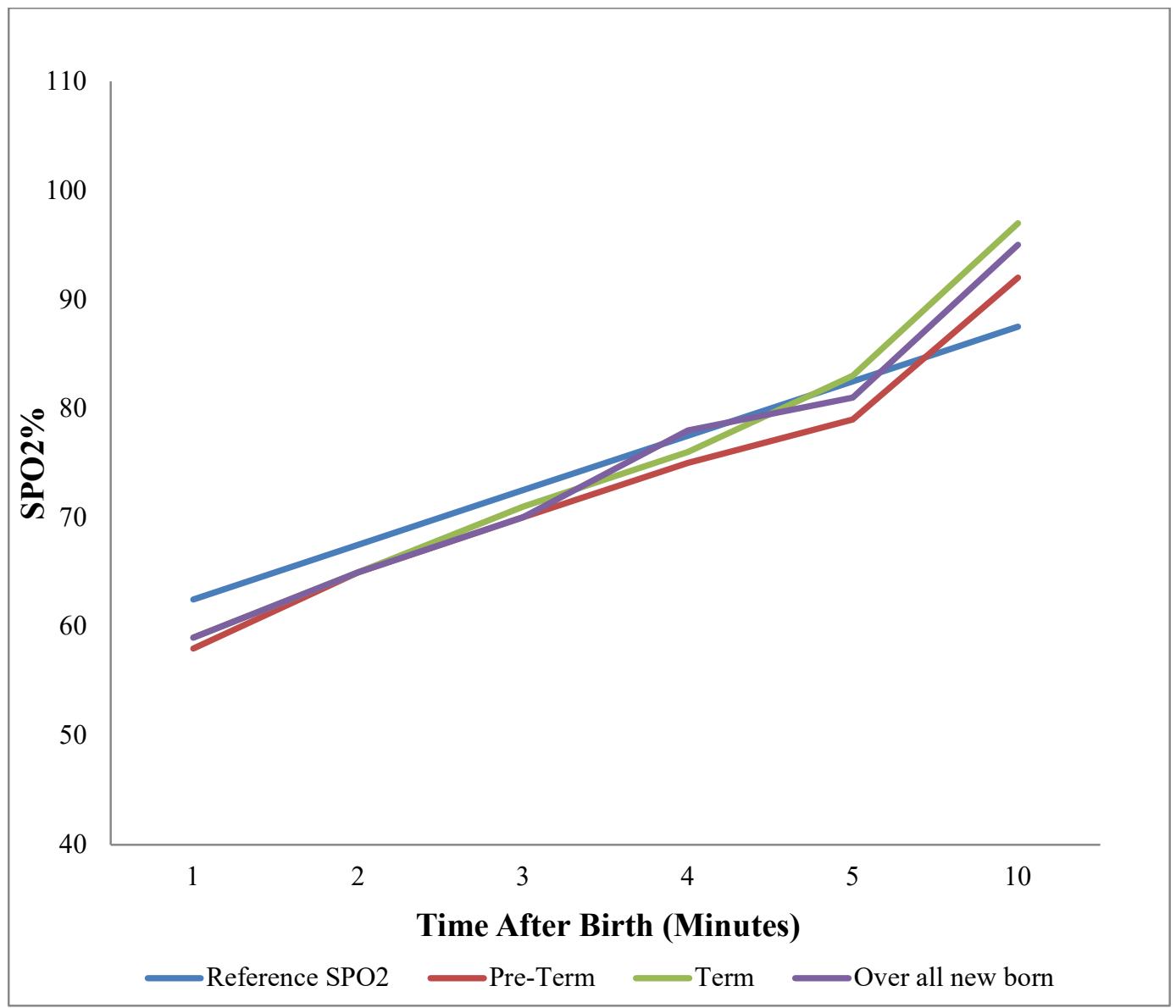

Figure- 3: Comparison of reference Spo2 with the median Spo2 of term, preterm and all newborns

\section{Discussion}

Whether a newborn requires oxygen or not has always been a matter of debate as no clear cut guidelines has been provided regarding the use of oxygen in neonatal resuscitation. American Academy of pediatrics and American Heart Association in their guidelines for neonatal resuscitation in 2010 has introduced the concept of pulse oximetry stating that pulse oximetry should be used for evaluation of oxygenation because assessment of colour is unreliable [3]. They also stated that in preterm newborns, especially in $<32$ weeks, oxygen should be used cautiously, titrating the concentration to the baby's oxygen saturation [3]. However no separate set of oxygen saturation ranges have been provided for preterm newborns. Recent observational studies have raised concerns that giving oxygen to target the saturation at "physiological" levels in newborn preterm babies may do more harm than good [5]. Many studies have identified various toxic effects of oxygen on the developing tissues of the preterm infant; however, optimal target $\mathrm{SpO} 2$ ranges have not been identified [10].
Why we need to have a separate set of reference target saturation for preterm newborns?

In the present study, it has been found that the $\mathrm{SpO}_{2}$ values of preterm newborns rises more slowly than that of term newborns and a statistically highly significant difference $(\mathrm{p} \leq 0.01)$ was found from birth till 1 minute of life though both the groups acquire $\geq 90 \%$ saturation within the 10 minutes period. It took a mean time \pm SD of $7.77 \pm 1.45 \mathrm{~min}$ (IQR of 6.3-9 minutes) for term newborns and $8.78 \pm 0.97 \mathrm{~min}$ (IQR of 8.3-9.3 minutes) for preterm newborns to reach $\geq 85 \% \mathrm{SPO}_{2}$ target and a mean time of $8.35 \pm 1.16 \mathrm{~min}$ (IQR of 7.3 to $9.3 \mathrm{~min}$ ) for term and $9.32 \pm 0.59 \mathrm{~min}$ (IQR of 9-10min) for preterm to reach the $\mathrm{SPO}_{2}$ target of $\geq 90 \%$. Thus the preterm newborns took longer to acquire the same target saturation as compared to the term newborns and if we use the same reference range for preterm newborns as that provided for term newborns, we have to erroneously flood them with oxygen which is actually not required. This fact may be explained by the 
different physiology of extra-uterine adaptation of preterm newborns as compared to term newborns and also due to presence of some residual shunts and late closure of ductus arterious [11]. Many other studies came out with the same result like Dawson et al found that it took a median of 7.9 minutes (IQR:5-10 minutes) to reach $\mathrm{SpO}_{2}$ of $\geq 90 \%$ and also showed that preterm newborns took longer than term newborns. The median $\mathrm{SpO}_{2}$ at 5 minutes for preterm newborns was $86 \%$ compared to $92 \%$ for term newborns $(\mathrm{p} \leq 0.001)$ [7]. Also in a study conducted by Nuntnarumit $\mathrm{P}$ et al in 2010 , it has been found that approximately half of the preterm newborns had a $\mathrm{SpO}_{2}$ of $<90 \%$ during the first 5 minutes of life and newborns with a lower gestational age seemed to have a lower $\mathrm{SpO}_{2}[12]$. Also in a study conducted by Shah et al to determine oxygen saturation profile in late-preterm and term infants, it has been found that the time required to reach Spo $2>90 \%$ was significantly different between late-preterm and term infants $(P=0.002)$ [13]. As little data is available about the percentiles of oxygen saturation for Indian newborns, the $3^{\text {rd }}, 10^{\text {th }}, 25^{\text {th }}, 50^{\text {th }}, 75^{\text {th }}, 90^{\text {th }}$ and $97^{\text {th }}$ percentiles of oxygen saturation have been calculated separately for term and preterm newborns and presented in the form of smooth curved percentile charts. Similarly $3^{\text {rd }}$ to $97^{\text {th }}$ percentiles of oxygen saturation were calculated by Jennifer and Dwson et al and Altuncu et al but were based on the studies conducted outside the India $[7,14]$.

The findings in the present study are comparable with the other studies supporting the assertion that oxyhemoglobin saturation does not reach $>90 \%$ until approximately 10 minutes of life during intra-uterine to extra-uterine transition. These percentiles could serve as a guide in deciding the use of oxygen during neonatal resuscitation because flooding spontaneously breathing newborns with excess oxygen can be unnecessarily invasive and lead to potentially harmful hyperoxia [15]. The Spo2 data obtained in each group at various time intervals was compared with the reference ranges provided in the NRP-2010 algorithm to know whether newborns in the Indian setup are able to follow it and it has been found that the findings in the present study are well consistent as those provided by ILCOR 2010. Most of the newborns acquire $>90 \%$ saturation with in the 10 minutes period though saturation at other time intervals are slightly on the lower side of the reference range provided. The whole procedure was carried out in strict accordance with the guidelines provided by American Academy of Pediatrics and American Heart Association using a new generation pulse oximeter with specially designed wrist-band neonatal probe. Secure fixation was done to reduce the motion artifacts. The main limitation of this study was time taken by the observer to fix and secure the probe and time taken by the pulse oximeter machine to record $\mathrm{SpO} 2$. Hence need of the time says that some more advanced measures should be devised to have an assessment of the oxygenation status of our newborns as soon as possible after birth.

\section{Conclusion}

The present study emphasizes on the routine use of pulse oximetry in the delivery room and to follow the recommendations of ILCOR along with the simultaneous use of percentile $\mathrm{SpO} 2$ normograms. As no clear cut-off of oxygen concentration to be used in delivery rooms in neonatal resuscitation has been provided, we have to rely on reference $\mathrm{SpO}_{2}$ targets. Preterm newborns should be treated separate from term newborns keeping in mind their different needs and requirements and separate set of reference oxygen saturation should be used for them. It is required that some more studies should be conducted on preterm newborns with larger sample size to have a more detailed idea about their $\mathrm{SpO}_{2}$ pattern progression.

\section{Acknowledgement}

The authors acknowledge the contribution of Dr.G.S Patel, Ex Dean, Gajra Raja medical College, Gwalior for providing all the help necessary for the conduction of this study. Authors are highly thankful to Dr. Ajay Gaur, Head of the Department, Pediatrics, for his constant support, motivation and guidance right from the beginning of the study. Authors are also thankful to the institutional Ethical Committee for giving their permission for the conduction of this study in the department.

\section{Funding: Nil, Conflict of interest: Nil Permission from IRB: Yes}

\section{References}

1. O'Donnell CP, Kamlin CO, Davis PG, Carlin JB, Morley CJ. Clinical assessment of infant colour at delivery. Arch Dis Child Fetal Neonatal Ed. 2007 Nov; 92(6):F465-7. Epub 2007 Jul 5.

2. Johnson K, Scott SD, Fraser KD. Oxygen use for preterm infants: factors that may influence clinical decisions surrounding oxygen titration. Adv Neonatal Care. 2011 Feb;11(1):8-14; quiz 15-6. doi: 10.1097/ ANC.0b013e318206d0c0. 
3. Perlman JM, Wyllie J, Kattwinkel J, Atkins DL, Chameides L, Goldsmith JP et al. Neonatal Resuscitation : 2010 International Consensus on Cardiopulmonary Resuscitation and Emergency cardiovascular Care Science with Treatment recommendations. Pediatrics; 126(5): 1319-1344.

4. Kattwinkel J, Perlman JM, Aziz K, Colby C, Fairchild K, Gallagher J, Hazinski MF et al. Part 15: neonatal resuscitation:2010 American Heart association Guidelines for Cardiopulmonary Resuscitation and Emergency Cardiovascular Care. Circulation. 2010; 122 (18 Suppl 3): 909-919.

5. Tin W, Gupta S. Optimum oxygen therapy in preterm babies. Arch Dis Child Fetal Neonatal Ed. 2007 Mar; 92(2):F143-7.

6. Ballard JL, Novak KK, Driver M. A simplified score for assessment of fetal maturation of newly born infants. J Pediatr. 1979 Nov;95(5 Pt 1):769-74.

7. Dawson JA, Kamlin CO, Vento M, Wong C, Cole TJ, Donath SM, Davis PG, Morley CJ. Defining the reference range for oxygen saturation for infants after birth. Pediatrics. 2010 Jun;125(6):e1340-7. doi: 10. 1542/peds.2009-1510. Epub 2010 May 3.

8. Tiwari S, Tiwari S, Nangia S, Saili A. Oxygen saturation profile in healthy term neonates in the immediate post natal period. Int J Clin Pediatr. 2013: 2 (1): 19-23.

9. O'Donnell CP, Kamlin CO, Davis PG, Morley CJ. Obtaining pulse oximetry data in neonates: a randomised crossover study of sensor application techniques. Arch Dis Child Fetal Neonatal Ed. 2005 Jan;90(1):F84-5.

10. Johnson K, Scott SD, Fraser KD. Oxygen use for preterm infants: factors that may influence clinical decisions surrounding oxygen titration. Adv Neonatal Care. 2011 Feb;11(1):8-14; quiz 15-6. doi: 10.1097/ ANC.0b013e318206d0c0.

11. Evans NJ, Archer LN. Postnatal circulatory adaptation in healthy term and preterm neonates. Arch Dis Child. 1990 Jan;65(1 Spec No):24-6.

12. Nuntnarumit $\mathrm{P}$, Rojnueangnit $\mathrm{K}$, Tangnoo $\mathrm{A}$. Oxygen saturation trends in preterm infants during the first 15 min after birth. J Perinatol. 2010 Jun;30(6):399402. doi: 10.1038/jp.2009.178. Epub 2009 Nov 5.

13. Shah PS, Hakak H, Mohamed A, Shah J, Young J, Kelly E. Oxygen saturation profile in late-preterm and term infants: a prospective cohort study. J Perinatol. 2014 Dec;34(12):917-20. doi: 10.1038/jp.2014.107. Epub 2014 Jun 5.

14. Altuncu E, Ozek E, Bilgen H, Topuzoglu A, Kavuncuoglu S. Percentiles of oxygen saturations in healthy term newborns in the first minutes of life. Eur J Pediatr. 2008 Jun;167(6):687-8. Epub 2007 Jul 20.

15. Rabi Y, Yee W, Chen SY, Singhal N. Oxygen saturation trends immediately after birth. J Pediatr. 2006 May;148(5):590-4.

\section{How to cite this article?}

Ambey R, Bansal A, Das G. Trends of Oxygen Saturation of Newborns after Birth from Northern India. Int J Pediatr Res.2016;3(6):446-454.doi:10.17511/ijpr.2016.i06.13. 